while doing so. Facilities available at one of the universities only may thus be made available for common use, and studies of insufficient general interest to make it worth while for each university to have its own department need not be duplicated; it is possible that some existing duplication can be eliminated and the funds thus set free used for urgent needs. At first sight, this proposed innovation seems a great break with the traditions of the older universities; but there is no doubt of its excellence in principle. The college authorities, it is expected, will be less in favour of it than the university, but this is probably all to the good. They will see to it that the proposed freedom to migrate for a term or more will not be abused; that, in fact, only those who will greatly benefit by the change will be encouraged to enjoy it. With respect to facilities for instruction and research in science, it is likely that Oxford students will benefit more than Cambridge from the new proposal, at least at the undergraduate stage. The honours man at Oxford in science has generally but one subject to specialize in and consequently has time to take extra courses elsewhere ; at Cambridge he is partly occupied with other subjects : and, of course, at Cambridge facilities for work in science are on a much more generous scale than at Oxford.

\section{Research in Social Studies}

THE Vice-Chancellor also spoke encouragingly of the scheme for research in social studies at Oxford made possible by the five-year grant from the Rockefeller Foundation which has now been in operation for a year. An institute of statistics has been started, several research lecturers have been appointed, and promising schemes of combined research in Colonial Government, in politics, in social services, and in economics have been begun. The first year of the experiment has been a great success. Research activity in other humane studies is also increasing remarkably. Since 1931 the number of those working for research degrees in the humane faculties has risen from 145 to 256 .

\section{Rhodes Memorial Lectures: Dr. E. Hubble}

THE Rhodes Memorial Lectures at Oxford will be delivered during the Michaelmas Term by Dr. Edwin Hubble, of the Mount Wilson Observatory. They will be given at 5 p.m. on October 29, November 12 and November 26 in the Milner Hall of Rhodes House, Oxford. The lectures will bear the general title of "The Observational Approach to Cosmology", and will deal in turn with the observational characteristics of that region of the universe accessible to telescopes now in operation, secondly with empirical tests of the physical nature of the spectroscopic 'red-shift', and finally in the third lecture with the possible models of the universe which follow from the previously established interpretation of 'red-shift'. Dr. Hubble, who is himself a former Rhodes scholar, is well known in England. As a result of his discovery of Cepheid variables in the extra galactic nebulæ, and his determination of their periods, nebulæ such as those in Andromeda were first definitely revealed as systems of stars comparable in dimensions with the huge galactic system of which our sun is a part. Working out from the nearer of these objects, and using his own determinations of their apparent luminosities, Hubble was enabled by statistical methods to find the distances of these objects in a volume of space of 300 million light years radius; from these distances and the velocity determinations of Slipher and Humason, he first established in 1929 the existence of a linear relation between distance and velocity (assuming the observed spectroscopic 'red-shift' to be due to Doppler effect).

HUBвLE's law, it need scarcely be added, is basic to all discussions of the expanding universe, whethor in the relativistic form of Lemaitre, Eddington and de Sitter, or in the kinematic form of Milne. As clearly set out in his Halley Lecture at Oxford in 1934, Hubble himself, however, has been led to seek whether there do not exist observational methods of determining whether this 'red-shift' is due to a velocity of recession, or to some other, as yet unspecified, physical cause. There will, therefore, be a widespread interest in his Rhodes Mernorial Lectures, not only because they will reveal the conclusions which he has reached in this matter, but also because they may be expected to show the results of the furthermost exploration of the universe which can be carried out with the existing instrumental equipment.

\section{Radcliffe Travelling Fellowship in Astronomy}

THE Board of Visitors of the University Observatory, Oxford, is inviting applications for the Radcliffe travelling fellowship in astronomy. This new fellowship in observational astrophysics, open to all suitably qualified astronomers irrespective of nationality, carries an annual salary not in excess of $£ 700$, the exact amount of which is fixed by the Board. The fellow will divide his time approximately equally between the new Radcliffe Observatory in Pretoria with its 74-inch reflecting telescope, and the University Observatory, Oxford, with its new solar equipment, and will work on problems of his own choosing in observational astrophysics. The tenure of the fellowship is normally three years, but this period may be extended (or shortened) if this seems desirable in the case of a successful candidate. The fellowship therefore represents a stage in restoring the balance between observational and theoretical astronomy in England, now overweighted in favour of the latter, and at the same time marks the beginning of a new period of friendly and close collaboration between the two observatories concerned. The fellowship is being financed by the Radcliffe trustees, as an earnest of their interest in the study of astronomy in Oxford, while the nomination to and the emoluments of the fellowship are in the hands of the University.

\section{The Harvard Tercentenary Celebrations}

Elsewhere in this issue (p. 667) we print an account of the impressive functions by which the tercentenary of the foundation of Harvard University 
at Cambridge, Massachusetts, was celebrated as an outstanding event in the history of knowledge by a great gathering representative of all branches of learning and drawn from all parts of the world. A tribute of a different character came from six of the industrial leaders of the United States, in the form of a letter to President Conant directing attention to the indebtedness of American industry to the universities. They pointed to the large and increas. ing number of university trained men in industry and business as evidence of the influence of university education on industrial progress, and stated that, having caught the spirit of research from the universities, industry has applied its methods successfully and with noteworthy results. During the past twenty-five years, the number of industrial research laboratories in the United States has grown from a handful to more than 1500 , and is rapidly increasing. "From the universities also flows much of the basic knowledge of science on which modern technical industry has built and will build in the future." The letter is signed by Walter S. Gifford, president of the American Telephone and Telegraph Company ; Alfred P. Sloan, jun., president of the General Motors Corporation; Thomas G. Watson, president of the International Business Machines Corporation; Pierre S. du Pont, chairman of the board of E. I. du Pont de Nemours and Company ; Owen D. Young, chairman of the board of the General Electric Company; and Walter C. Teagle, president of the Standard Oil Company of New Jersey. It is a striking tribute to the significance of university institutions in industrial progress.

\section{African Problems}

A WIDE and varied field was covered in the discussions which engaged the attention of the twenty. third biennial session of the International Colonial Institute held in London on October 6-8. As Mr. Ormsby-Gore pointed out in a speech at the banquet at which the delegates were entertained by the British Government, the Colonial Powers are all confronted with a number of problems, human, political and social, which have to be studied objectively in common. To this end the mere interchange of views and experience is useful, even though no very decisive conclusion may appear to emerge. In this respect, the pooling of experience and discussion of methods of meeting the new problems raised by the introduction of newspapers, broadcasting and the cinema are highly instructive. This, too, is perhaps the most beneficial outcome it is legitimate to expect from the discussion of the detribalized native, which was opened by Lord Lugard and occupied a considerable part of the session. It was evident, as might have been anticipated, that measures applicable to one area may not be possible in another. Thus the conclusion put forward by Father Charles, that tribalism can be revived successfully only under rule on tribal lines and by the use of native courts, may be accepted as a general proposition. Clearly, however, it cannot meet transitional cases, such as those to which $\mathrm{Mr}$. Ormsby-Gore referred, when he spoke of the product emerging under missionary influence, for example, in the towns of the west coast, which it is difficult to fit into the evolution and progress of tribal life and the social organism. On the other hand, Prof. Basil Williams, while expressing approval of the system in the Belgian Congo, under which the mine-workers are encouraged to bring their wives, admitted that it has been impressed upon him that such a system would not be practical on the Rand, where mineworkers number a quarter of a million.

\section{Natural Resources Conservation}

ONE of the important questions discussed at the recent World Power Conference was the conservation of natural resources. Science Service, of Washington, D.C., has issued reports of papers, dealing with this subject, which formed the basis of a discussion at the Conference. It is stated that whether the business systems are capitalist or socialist or a combination of the two, we must organize our activities to meet the demands of natural law, and all civilized nations are struggling towards this end each in its own way. The principles laid down for 'resource planning' by the writer of the reports are to keep soil, water, forest and grass as at present, but to economize by every possible means in the use of irreplaceable minerals. Nature lays down the terms, and we must either obey or suffer. We can come to terms with Nature in regard to the self-renewing resources by using them only as fast as they are replaced. With regard to the non-replaceable minerals, we can come to terms only by finding new and abundant substitutes faster than we use up the older materials. It is a race between technology and waste. Face to face with the inexorable demands of Nature, we suffer from human weakness. The consent of the people has to be obtained in spite of the propaganda issued by those whose interests are opposed to the public welfare. The laws of a federal union of sovereign States are a tangle of inconsistent rights and powers that hampers the action of the nation. The United States are now struggling to acquire legal and political powers commensurate with their necessities. If it fails, we are thruatened by a crisis when essential materials are exhausted and it becomes necessary to reduce the population.

\section{British Chemical Manufacturers}

REPoRtING on its activities during the year ended May 31, 1936, the Association of British Chemical Manufacturers justly claims to have rendered substantial assistance to an industry which is one of our most important national assets. It is concerned with the organization of displays of British goods, such as that provided by the British Industries Fair, with legislation and the incidence of taxation, with commercial treaties with foreign countries, with the Ottawa agreements and means for stimulating trade within the Empire, with transport, safety precautions, and in fact with any problem relating to the industry other than questions involving wages, hours and conditions of work. There is, however, much still to be done, and the Association is anxious to realize 